\title{
Determination of zones at risk for fasciolosis in the department of Haute-Vienne, central France: a retrospective study on natural infections detected in 108,481 Galba truncatula for 37 years
}

\author{
Philippe Vignoles, Daniel Rondelaud, and Gilles Dreyfuss* \\ INSERM 1094, Faculties of Medicine and Pharmacy, 2 rue du Docteur Raymond Marcland, 87025 Limoges Cedex, France
}

Received 11 October 2017, Accepted 3 December 2017, Published online 22 December 2017

\begin{abstract}
A retrospective study on the natural infection of Galba truncatula by Fasciola hepatica was carried out in the French department of Haute-Vienne to determine whether there are areas at risk for fasciolosis. Adult snails included in this analysis came from samples collected from pastures on 259 farms and from 121 wild watercress beds between 1970 and 2006. Fasciola hepatica infection rates were examined in relation to altitude and climatic data (mean annual rainfall, mean annual temperature) of each municipality. In a total of 108,481 snails collected in 151 municipalities, the overall prevalence of infection was $3.8 \%$ but varied according to the municipalities from which samples were taken (from $1 \%$ to $7.4 \%$ ). The prevalence of $F$. hepatica infection in snails significantly decreased when the mean altitude of municipalities or their mean annual rainfall increased. However, this prevalence significantly increased with increasing mean annual temperatures. Studying the prevalence of infection in these snails makes it possible to delineate zones at risk for fasciolosis on the acid soils of Haute-Vienne. The risk of infection for livestock would be greater in areas of Haute-Vienne below $400 \mathrm{~m}$ above sea level and would gradually decrease when the altitude of the land increases.
\end{abstract}

Keywords: Altitude, at risk zones, climate, Fasciola hepatica, Galba truncatula, Haute-Vienne, snails

Résumé - Détermination des zones à risque pour la fasciolose dans le département de la HauteVienne (France) : une étude rétrospective sur les infestations naturelles détectées chez 108.481 Galba truncatula pendant $\mathbf{3 7}$ années. Une étude rétrospective sur l'infestation naturelle de Galba truncatula par Fasciola hepatica a été effectuée dans le département de la Haute-Vienne pour déterminer s'il existe des zones à risque pour la fasciolose. Les limnées adultes impliquées dans cette analyse proviennent d'échantillons prélevés dans les pâturages de 259 fermes et dans 121 cressonnières sauvages entre 1970 et 2006. Les taux d'infection par Fasciola hepatica ont été mis en relation avec l'altitude et les données climatiques (précipitations annuelles moyennes, température annuelle moyenne) de chaque municipalité. Sur un total de 108.481 limnées récoltées dans 151 municipalités, la prévalence globale de l'infestation était de 3,8\%, mais variait selon les municipalités dans lesquelles les échantillons ont été prélevés (de $1 \%$ à $7,4 \%$ ). La prévalence de l'infestation par F. hepatica diminue considérablement lorsque l'altitude moyenne des municipalités ou leurs précipitations annuelles moyennes augmente. D'autre part, cette prévalence augmente considérablement avec l'augmentation de la température annuelle moyenne des municipalités. L'étude de la prévalence de l'infestation chez ces limnées permet de délimiter des zones à risque pour la fasciolose sur les sols acides de la Haute-Vienne. Le risque d'infestation pour le bétail serait plus élevé dans les zones de la Haute-Vienne situées en dessous de $400 \mathrm{~m}$ d'altitude et diminuerait graduellement lorsque l'altitude de ces terrains augmente.

\section{Introduction}

Fasciolosis is a worldwide parasitosis caused by the liver fluke Fasciola hepatica Linnaeus, 1758 [30]. It affects humans, but its main definitive hosts are ruminants such

\footnotetext{
*Corresponding author: gilles.dreyfuss@unilim.fr
}

as cattle and sheep [37-38]. In most countries of the world where these ruminants are reared, this disease is responsible for significant economic losses [25]. The transmission of the disease to other definitive hosts requires a freshwater gastropod, which ensures the development of $F$. hepatica larval forms until the emission of cercariae. The latter become attached to vegetation and 
turn into metacercariae, thus becoming infectious forms [5]. In Western Europe, Galba truncatula O.F. Müller, 1774 [41] is the common snail host of F. hepatica [14,57]. However, other species of Lymnaeidae such as Omphiscola glabra O.F. Müller, 1774 [41] are also capable, to varying degrees, of being intermediate hosts $[7,38,65]$.

The development of $G$. truncatula populations and, consequently, of $F$. hepatica larval forms is dependent on the climate in the region or country where this lymnaeid lives. The most favourable conditions are temperatures ranging between $10^{\circ} \mathrm{C}$ and $25^{\circ} \mathrm{C}$ and high relative humidity depending on atmospheric precipitation. As a result, the disease is common in temperate regions like most European countries. This relationship between climate and the parasitosis was demonstrated by the observations of Weybridge researchers in England [44-46]. Other authors have broadened this relationship between parasitosis and climate by incorporating other factors such as vegetation growth, local climatic variations (microclimate) and pasture topography [34-35]. The existence of this relationship has since been verified by numerous authors [15,39,47].

The relationship between climate and fasciolosis has led to the development of predictive models to estimate the risk related to this disease. Using different approaches, including the Geographical Information System, several authors have specified endemic areas for fasciolosis in different countries of the world such as Brazil [3], Bolivia [17], Cambodia [62], Ethiopia [66], Iran [22], Ireland [60], Sweden [42], Switzerland [6], the United Kingdom [15] or the United States [34]. Several climatic forecast indices were also used to indicate the chances of disease transmission for each month of the year. Moreover, the accumulated values of these climate risk indices allowed researchers to define the beginning and end of fasciolosis transmission for each year and the classification of endemic zones by low, moderate and high degrees of risk [18]. Most models were mainly validated by means of surveys on the prevalence of $F$. hepatica infection in the definitive host $[33,63]$. In contrast, those using data on the intermediate host are much less numerous $[6,48]$.

In France, no map delimiting areas at risk for fasciolosis has yet been published. According to Chauvin et al. [10], these risk areas are represented by all the water points where the host snail lives. However, the main outbreaks of the animal disease were in breeding areas such as Burgundy, Centre, Lorraine, Normandy, South-West and Vendee $[9,19]$. The Limousin region is also affected by the disease since cases of fasciolosis have been reported in the last twenty years. Cases of human fasciolosis were detected between 1955 and 1998 in 860 people, most of them living in Limousin [55-56]. A prevalence of $13 \%$ (out of 12,724 cattle examined between 1983 and 1985) was reported by Mage [31] in the same area. This value has been confirmed in another paper by Mage et al. [32], reporting a prevalence of $17.1 \%$ (out of 12,389 cattle) in the department of Corrèze between 1990 and 1999. As the climatic conditions prevailing in this region are favourable for the development of G. truncatula populations [14], it was interesting to determine whether there were variations in the risk intensity for fasciolosis via the following two questions: did the native populations of $G$. truncatula show variations in the prevalence of their natural infection with $F$. hepatica in relation to the relief and climatic conditions of the Limousin municipalities? Could areas at risk for fasciolosis be identified in this region based on the natural infection of snails? To answer these two questions, a retrospective study was carried out on snails that our team collected between 1970 and 2006 from pastures of farms with reported animal fasciolosis or from wild watercress beds at the origin of human fasciolosis cases. Other data were obtained from samples taken from farms in which snails have been experimentally transplanted. Among the three departments of Limousin, the Haute-Vienne was chosen for this study because of numerous samples of snails collected by our team in this area from the 1970s. The results obtained in several farms or in several wild watercress beds have already been reported [1-2,32,52]. In contrast, the data on the natural infection of other snail populations have not yet been published.

\section{Materials and methods \\ Study area}

The department is located in the north-western part of the Massif Central (Fig 1). The latitude of this area ranges from $45^{\circ} 26^{\prime}$ to $46^{\circ} 21^{\prime} \mathrm{N}$, while its longitude ranges from $0^{\circ} 48^{\prime}$ to $1^{\circ} 34^{\prime} \mathrm{E}$ (https://www.coordonnees-gps.fr). Its surface area is about $5520 \mathrm{~km}^{2}$ and its altitude varies between $160 \mathrm{~m}$ in the valley of the Vienne and $777 \mathrm{~m}$ at the Crozat Mount, located near the lake of Vassivière. The department is not really divided into distinct geographical entities, but three large groups can be identified: the Basse Marche (altitude, 150-300 m) in the northern third, the valleys of Vienne and its tributaries (altitude, 150-400 m) largely located in the central part, and the plateaus and mounts of Limousin (altitude, 300-777 m) along the eastern, south-eastern and south-western borders of the department [11]. The Haute-Vienne is constituted of crystalline grounds dating back to the primary era and these grounds were folded during the formation of this Hercynian chain. The subsoil is mainly composed of granite or gneiss, with some outcrops of mica-schist or serpentinite. The result is the presence of numerous rivers: more than $7000 \mathrm{~km}$, of which the main one is the Vienne. Owing to the nature of soils, the $\mathrm{pH}$ of running water ranges from 5.6 to 7 and the level of dissolved calcium is generally less than $20 \mathrm{mg} / \mathrm{L}$ [21]. The continental type climate is attenuated by moist winds coming from the Atlantic Ocean. However, in its eastern part, the climate undergoes a mountainous influence due to the proximity of the Massif Central [11]. The Haute-Vienne is predominantly rural and the human activity is mainly focused on livestock and silviculture: the department comprises 168,000 ha of natural grassland and 149,996 ha of wood, which corresponds to $33.1 \%$ and $29.6 \%$ of its area, respectively. 


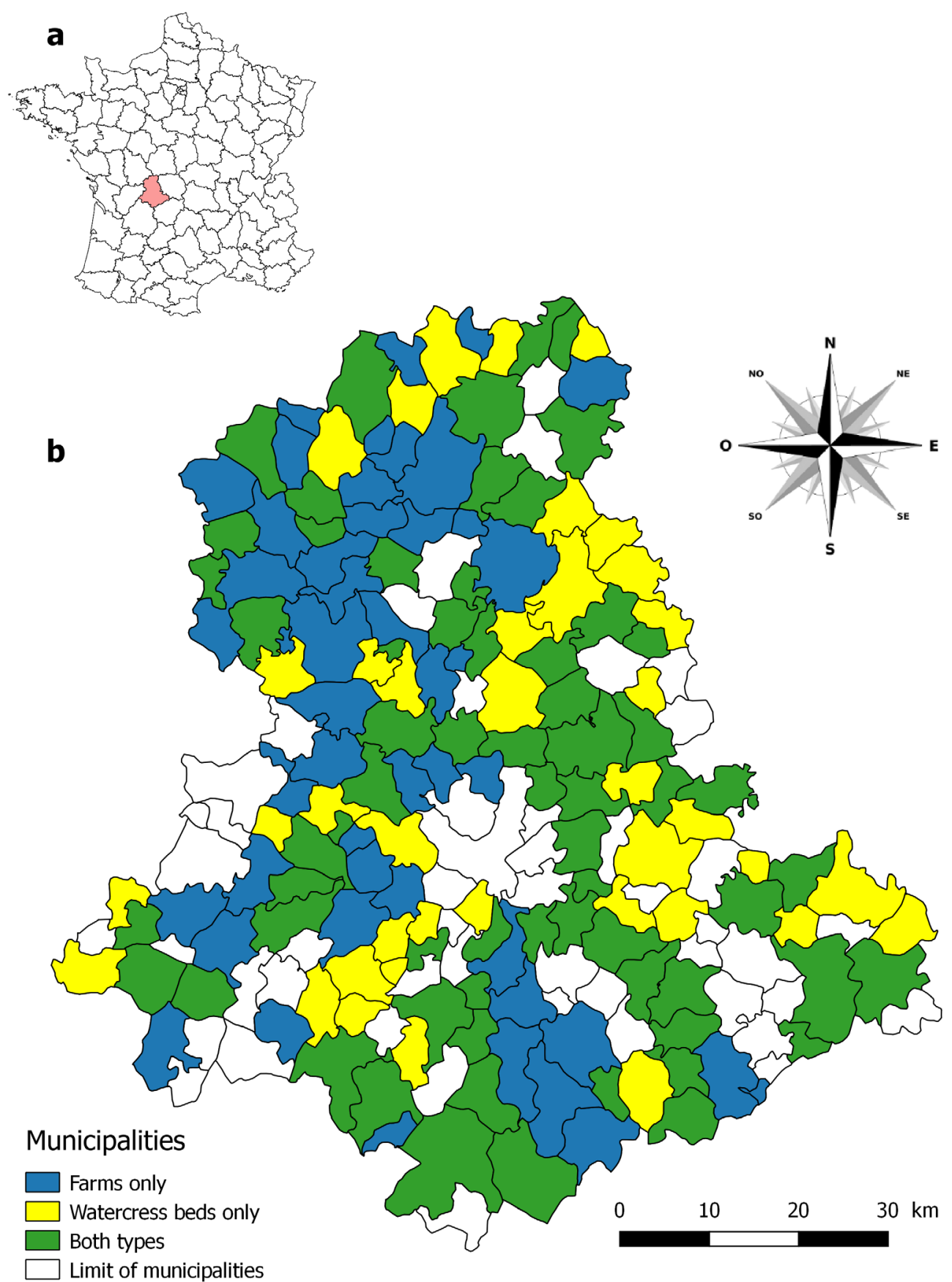

Figure 1. Geographical location of the department of Haute-Vienne in central France (a) and the 151 municipalities on which the 259 farms and 121 wild watercress beds are located (b). No snail samples were taken in municipalities in white.

\section{Snail populations}

The populations selected for this study are those in which regular or irregular sampling of $G$. truncatula occurred over several consecutive years. We did not take into account snail habitats in which occasional sampling was carried out to detect a natural infection of snails or to perform experimental infections in the laboratory. Table 1 shows the type of habitats colonized by $G$. truncatula, the dates of these investigations and the total number of snail samples collected. Figure 1 shows the 151 municipalities of the department on which these samples were taken. Two habitat groups were considered. The first group was represented by snail habitats present in the swampy grasslands of 259 farms breeding cattle or sheep. The first 234 were prospected for the first time between 1970 and 1999 when one or more cases of animal fasciolosis were detected by the local veterinarians. They were again investigated between 1976 and 2006 when new cases of fasciolosis were discovered. Each investigation was carried out in March or April because all snail habitats are then waterlogged [58] and a sample of snails was taken each 
Table 1. Main characteristics of the different snail habitats, with indications of the number of snail samples.

\begin{tabular}{|c|c|c|c|c|}
\hline \multirow{2}{*}{$\begin{array}{l}\text { Type of snail habitat (number of } \\
\text { farms or beds) }\end{array}$} & \multirow[t]{2}{*}{ Period of study } & \multicolumn{2}{|l|}{ Snail samples } & \multirow[t]{2}{*}{ Number of snails per sample } \\
\hline & & $\begin{array}{l}\text { Number per farm } \\
\text { or per bed }\end{array}$ & Total number & \\
\hline \multicolumn{5}{|l|}{ Grasslands on farms } \\
\hline $\begin{array}{l}\text { Systematic survey for } \\
\text { fasciolosis }(234)\end{array}$ & 1970-2006 & 2,3 or 4 & 515 & $\begin{array}{l}\text { From } 100 \text { to } 150 \\
\text { (several habitats per farm) }\end{array}$ \\
\hline Experimental transplantations (25) & $1986-1995$ & 10 & 250 & $\begin{array}{l}50 \text { or } 100 \text { (a single habitat } \\
\text { per farm)* }\end{array}$ \\
\hline \multicolumn{5}{|l|}{ Wild watercress beds } \\
\hline Regular sampling (45) & $\begin{array}{l}1974-1989 \\
1990-2006\end{array}$ & $\begin{array}{l}1 \text { or } 2 \\
15\end{array}$ & $\begin{array}{l}68 \\
675\end{array}$ & From 10 to 50 per bed ${ }^{*}$ \\
\hline Irregular sampling (76) & $1974-1998$ & 4 & 304 & From 10 to 50 per bed* \\
\hline Totals & - & - & 1812 & \\
\hline
\end{tabular}

* Depending of the size of the snail population.

time to look for larval forms of $F$. hepatica. The remaining 25 farms were selected because of a field experiment carried out by our team on transplantations of snails from their original habitats into new areas [64]. Snail sampling was also performed each year in March between 1986 and 1995. The second group of habitats concerns wild watercress beds at the origin of human fasciolosis cases [50,54-55]. Forty-five of these beds were first prospected between 1974 and 1989, following the discovery of one or more cases of human distomatosis and one or two samples of $G$. truncatula were taken from each bed in subsequent years to determine the prevalence of $F$. hepatica infection in snails. Each bed was then reinvestigated each year from 1990 to 2006 to collect samples of snails and follow up on their parasitic contamination [14,57]. The other 76 beds were irregularly followed up between 1974 and 1998, with four snail samples taken during this period to detect possible changes in the prevalence of their natural infection with $F$. hepatica $[50-51,56]$. In both cases, snails were collected in June or early July.

\section{Snail investigations}

Only adult lymnaeids (from 4-5 to 8-9 mm shell height) belonging to the overwintering generation were collected in these samples. The juveniles and pre-adults were not taken into account so as not to endanger the survival of each population. On each farm surveyed for fasciolosis, snail habitats were detected using the indicator plant method [58] and snails were randomly searched at sight in open drainage furrows and spring heads present in grasslands to obtain a final sample of 100-150 individuals per farm (with a number of snails ranging from 14-18 to 25-30 adults per habitat depending on its area). In each of the other 25 farms, snail habitats were found using the same method and a sample of 50 or 100 snails depending of the size of the population was taken from the same habitat (Table 1 ). The choice of March or April for sampling was dependent on the altitude of the habitats and the period during which cercarial shedding occurred in the Limousin region: April or May, respectively [14,57]. In the wild watercress beds, the number of snails taken in each sample (from 10 to 50 adults per habitat) was dependent on the size of the snail population (Table 1). It also depended on the altitude of these beds and the date of cercarial shedding in the natural environment (July or August, respectively).

After their collection, the snails were transported on wet grass to the laboratory under constant conditions (generally $20^{\circ} \mathrm{C}$ ). They were then dissected under a stereomicroscope to find larval forms of $F$. hepatica (rediae and/or cercariae). The rediae of $F$. hepatica have been differentiated from those of Calicophoron daubneyi over the length of their body, the presence of appendages $(F$. hepatica) and the morphology of their pharynx [14,57]. The cercariae of $F$. hepatica have also been identified on their presence in the body of their rediae when they are well differentiated (the procercariae of $C$. daubneyi emerge very early from the body of their parental rediae and finish their differentiation in the visceral cavity of the snail) and on their characteristic white colour $[14,57]$. Snails having only sporocyst(s) in their bodies were not counted because the sporocyst shape and its dimensions do not allow us to identify the digenean species in most cases. No molecular biology study was carried out during the period of snail investigations (1970-2006) to detect the presence of the parasite within the snail.

\section{Geographical and climatic data}

The mean altitude of each municipality was obtained by considering that of its main city and was determined using the Carte-de-France website (http://www.cartesfrance.fr). The other two variables were the mean annual rainfall and the mean annual temperature from 1971 to 2000, and came from maps published by Météo France [40].

\section{Statistical analyses}

The prevalence of $F$. hepatica infection was calculated using the ratio between the number of infected snails and that of adult snails collected from a farm or a watercress bed. The individual values obtained for the different farms 


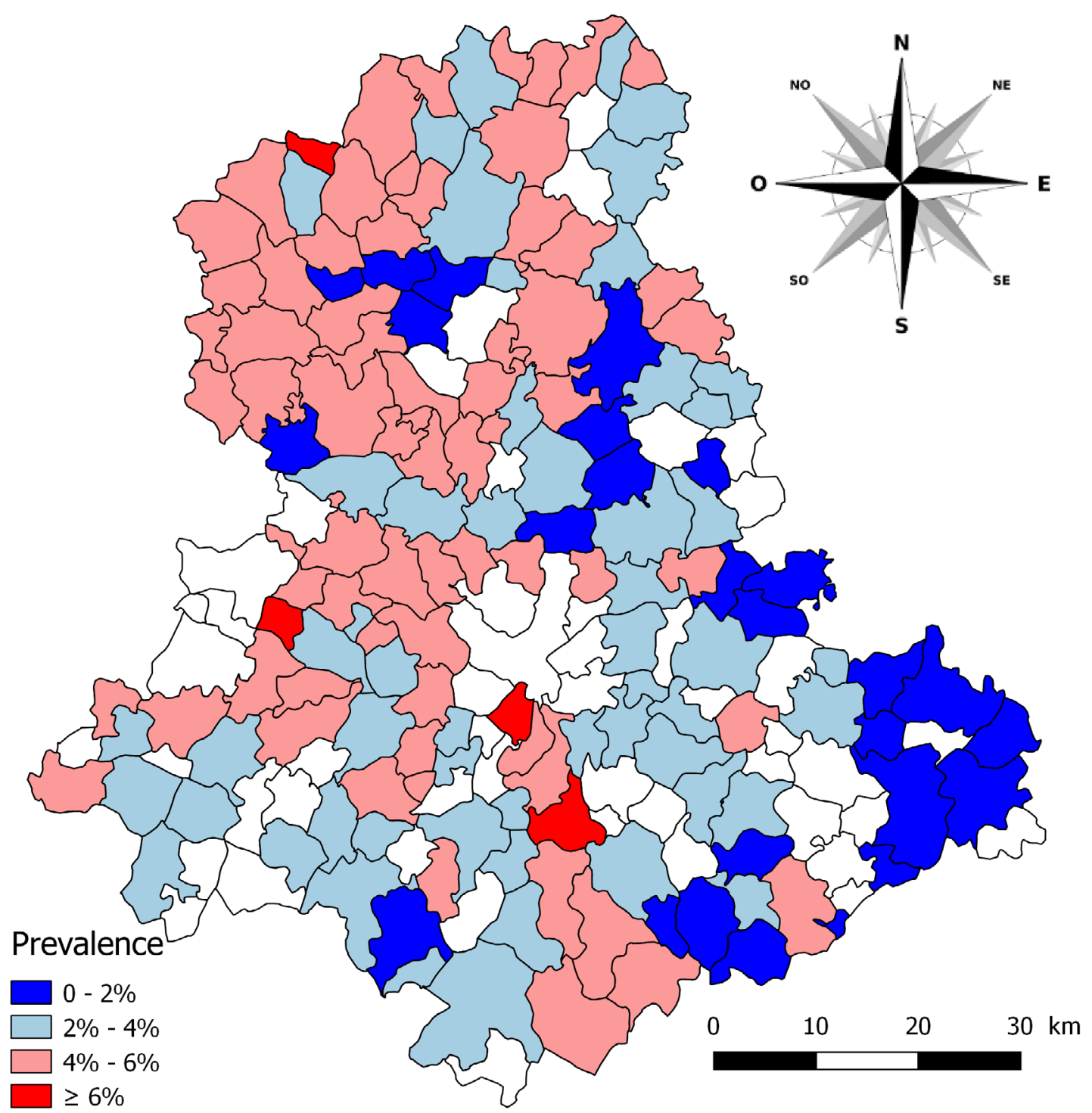

Figure 2. Prevalence of natural infection with Fasciola hepatica in the 151 municipalities of the Haute-Vienne department on which snail samples were collected between 1970 and 2006. No snail samples were taken in municipalities in white.

and watercress beds in a given municipality were then pooled to obtain a mean prevalence. The results are shown in Figure 2.

Different categories for the mean altitude of municipalities, their mean annual rainfall or their mean annual temperature were used according to the data provided by the Carte-de-France website (altitude) or the maps published by Météo France [40]. These categories have been chosen so that they have identical amplitude. As the altitude of farms and watercress beds ranged from $160 \mathrm{~m}$ to $570 \mathrm{~m}$, the individual values noted for the prevalence of natural infection in snails were classified in the following four categories of altitude: $<300 \mathrm{~m}, 300-400 \mathrm{~m}, 401-500 \mathrm{~m}$, and $>500 \mathrm{~m}$. Five categories were also used for mean annual rainfall $(<900 \mathrm{~mm}, 900-1000 \mathrm{~mm}, 1001-1100 \mathrm{~mm}$, $1101-1200 \mathrm{~mm}$, and $>1200 \mathrm{~mm})$, whereas five other categories $\left(<9.5^{\circ} \mathrm{C}, 9.5-10^{\circ} \mathrm{C}, 10.1-10.5^{\circ} \mathrm{C}, 10.6-11^{\circ} \mathrm{C}\right.$, and $>11^{\circ} \mathrm{C}$ ) were used for the mean annual temperature.
Values for altitude, annual rainfall and annual temperature were first subjected to a Pearson's correlation test to assess the degree of relationship between these three parameters. As the latter were strongly correlated with each other (Table 3), the values given in the above categories of altitude, rainfall or temperature were subjected to a simple linear regression instead of being processed by multiple linear regression. The different analyses were performed using the R 3.3.0 software [49]. All prevalence values are given with their $95 \%$ confidence intervals.

\section{Results}

Out of a total of 108,481 snails collected in 151 municipalities, the overall prevalence of infection was $3.8 \%$ with insignificant differences between percentages found in snails from grasslands (3.1\%-3.9\%) and those from 
Table 2. Prevalence of Fasciola hepatica infection in snail samples collected from breeding farms and wild watercress beds in HauteVienne. CI, confidence interval.

\begin{tabular}{|c|c|c|c|}
\hline \multirow[t]{2}{*}{ Type of snail habitat (number of farms or beds) } & \multicolumn{2}{|c|}{ Total number of snails } & \multirow{2}{*}{$\begin{array}{l}\text { Prevalence in \% } \\
{[95 \% \text { CI }]}\end{array}$} \\
\hline & collected & infected & \\
\hline \multicolumn{4}{|l|}{ Grasslands on farms } \\
\hline Systematic survey for fasciolosis (234) & 67,129 & 2666 & $3.97[3.82 ; 4.12]$ \\
\hline Experimental transplantations (25) & 14,000 & 434 & $3.10[2.81 ; 3.40]$ \\
\hline \multicolumn{4}{|l|}{ Wild watercress beds } \\
\hline Regular sampling (45) & 15,394 & 623 & $4.05[3.74 ; 4.37]$ \\
\hline Irregular sampling (76) & 11,958 & 442 & $3.70[3.36 ; 4.05]$ \\
\hline Totals & 108,481 & 4165 & $3.84[3.72 ; 3.96]$ \\
\hline
\end{tabular}

Table 3. The results provided by the Pearson's correlation test when analysing values for the mean altitude, mean annual rainfall and mean annual temperature in the various municipalities of Haute-Vienne. CI, confidence interval.

\begin{tabular}{llll}
\hline Pearson's correlation coefficients $(95 \%$ CI $)$ & & \\
\hline Parameters & Mean altitude & Mean annual rainfall & Mean annual temperature \\
\hline Mean altitude & 1 & 0.794 & -0.749 \\
& & $(0.726 ; 0.846)^{* * *}$ & $(-0.812 ;-0.670) * * *$ \\
Mean annual rainfall & 0.794 & 1 & -0.735 \\
Mean annual temperature & $(0.726 ; 0.846)^{* * *}$ & & $(-0.800 ;-0.652) * * *$ \\
& -0.749 & -0.735 & 1 \\
\hline
\end{tabular}

$* * * p<0.001$.

watercress beds $(3.7 \%-4 \%$, Table 2$)$. In contrast, this prevalence varied according to municipalities with a minimum of $1 \%$ at Domps and a maximum of $7.4 \%$ at Saint-Jean-Ligoure. Figure 2 shows the distribution of these percentages in the 151 municipalities. Prevalences between $4 \%$ and $6 \%$ were found in most municipalities of Haute-Vienne, irrespective of their geographical location. Values above $6 \%$ were recorded in only four municipalities in the west and the south of this department. In contrast, the lowest values $(<2 \%)$ were noted for the municipalities (in dark blue) located in the Blond Mounts (north-western part of Haute-Vienne), the Ambazac Mounts (northeastern part) and the Limousin Mounts located along the eastern, south-eastern and south-western borders of the department. This decrease in prevalence values was significantly correlated $(p<0.001)$ with the increasing altitude of municipalities, as shown in Table 4(prevalence) and 5 (linear regression). This model could explain $50.7 \%$ of total variance in the prevalence of snail infection with F. hepatica.

Figure 3 shows variations in mean annual rainfall in the 200 municipalities of Haute-Vienne. Annual rainfall was closely related to the mean altitude of the municipalities (Table 3). The lowest precipitations were noted in the municipalities at the northern limit of Haute-Vienne and these values increased in intensity towards the south of the department. The most abundant precipitations ( $>1200 \mathrm{~mm}$ per year) were noted in the communes on the eastern, south-eastern and south-western borders of the department, where the Limousin Mounts are located. A significant relationship $(p<0.001)$ between the decrease in prevalence in snails and the increase in mean annual precipitations was noted, as shown in Tables 4 and 5. However, this model based on the annual precipitations can only explain $25.2 \%$ of total variance in the prevalences recorded in G. truncatula (Table 5). On the other hand, the mean annual temperature (Figure 4) has an inverse distribution in the department, with the highest values in the municipalities located in the north and west, while the lower ones are on the eastern and south-eastern borders. There was also a significant $(p<0.001)$ and positive relationship between the increase in prevalence and that of the mean annual temperature in municipalities (Tables 4 and 5). The latter model explains $29.3 \%$ of total variance in the prevalences observed in snails (Table 5).

When both types of breeding farms (cattle or sheep) are located in the same municipalities, no significant difference between prevalence values in snails was noted, regardless of the factor considered.

\section{Discussion}

The overall prevalence of $F$. hepatica infection in adult snails collected in Haute-Vienne was 3.8\% (Table 2) in the 
Table 4. Prevalence of natural infection with Fasciola hepatica in Galba truncatula collected from the department of Haute-Vienne between 1970 and 2006 in relation to different categories for the mean altitude, mean annual rainfall and mean annual temperature. CI, confidence interval.

\begin{tabular}{llll}
\hline Parameter and categories & Number of infected snails & Number of snails collected & Prevalence (\%) of natural infection [95\% CI] \\
\hline Mean altitude & & & \\
$<300 \mathrm{~m}$ & 1933 & 42,216 & $4.58[4.38 ; 4.78]$ \\
{$[300 ; 400 \mathrm{~m}[$} & 1883 & 47,501 & $3.96[3.79 ; 4.14]$ \\
{$[400 ; 500 \mathrm{~m}[$} & 317 & 16,620 & $1.91[1.70 ; 2.13]$ \\
$\geq 500 \mathrm{~m}$ & 32 & 2144 & $1.49[1.02 ; 2.10]$ \\
Total & 4165 & 108,481 & $3.84[3.72 ; 3.96]$ \\
Mean annual rainfall & & & \\
$<900 \mathrm{~mm}$ & 363 & 7679 & $4.73[4.26 ; 5.23]$ \\
{$[900 ; 1000 \mathrm{~mm}[$} & 1671 & 36,605 & $4.33[4.12 ; 4.54]$ \\
{$[1000 ; 1100 \mathrm{~mm}[$} & 1474 & 39,570 & $3.73[3.54 ; 3.92]$ \\
{$[1100 ; 1200 \mathrm{~mm}[$} & 602 & 19,983 & $3.01[2.77 ; 3.26]$ \\
$\geq 1200 \mathrm{~mm}$ & 55 & 2644 & $2.08[1.57 ; 2.70]$ \\
Total & 4165 & 108,481 & $3.84[3.72 ; 3.96]$ \\
Mean annual temperature & & \\
$<9.5^{\circ} \mathrm{C}$ & 1 & 100 & $1.00[0.03 ; 5.45]$ \\
{$\left[9.5 ; 10^{\circ} \mathrm{C}[\right.$} & 100 & 5255 & $1.90[1.55 ; 2.31]$ \\
{$\left[10 ; 10.5^{\circ} \mathrm{C}[\right.$} & 119 & 4235 & $2.81[2.33 ; 3.35]$ \\
{$\left[10.5 ; 11^{\circ} \mathrm{C}[\right.$} & 1509 & 41,437 & $3.64[3.46 ; 3.83]$ \\
$\geq 11^{\circ} \mathrm{C}$ & 2436 & 57,454 & $4.24[4.07 ; 4.41]$ \\
Total & 4165 & 108,481 & $3.84[3.72 ; 3.96]$ \\
\hline
\end{tabular}

present study, with negligible differences between percentages observed in grasslands and those found in watercress beds. Different percentages were reported in Europe by the authors who dissected or analysed by molecular biology a large number of $G$. truncatula to find larval forms of $F$. hepatica. In Great Britain, the mean prevalence was less than $2 \%$ in more than $52,000 \mathrm{G}$. truncatula dissected by Ollerenshaw [43] between 1960 and 1969. In Spain, the prevalence was $11.4 \%$ in the 5486 snails dissected by Manga-González et al. [36], but was only $4.4 \%$ in the 1141 snails dissected by Iglesias-Piñeiro et al. [24]. A molecular biology study revealed a prevalence of $7.0 \%$ in 4733 G. truncatula collected from 70 Swiss farms [59]. In the French region of Limousin, the prevalence of natural infection in dissected snails was $5.1 \%$ in $18,791 G$. truncatula from grasslands of 141 farms [32] and only $1.7 \%$ in 19,249 adult snails collected from 59 watercress beds [13,52]. The difference between our results and those of the above authors can be explained by the nature of the material studied (pre-adult snails, when collected, are usually more numerous than adults in a population of G. truncatula) and the method used to detect infected snails (the latter are more numerous in a molecular biology study due to the counting of snails containing only sporocysts of $F$. hepatica). However, another hypothesis, based on the existence of a higher parasitic pressure in the grasslands of farms which intensively bred their livestock since the 1970s $[8,29]$, cannot be excluded to explain this prevalence of $3.8 \%$ reported in this study.
In Haute-Vienne, the prevalence of $F$. hepatica infection in snails significantly decreased with the increasing altitude of municipalities. The lowest prevalence values $(<2 \%)$ were noted in municipalities whose altitude exceeds $400 \mathrm{~m}$ and more. This result is rather difficult to interpret due to a relative lack of information on this point in the literature. Rapsch et al. [48] reported that the risk of $F$. hepatica infection in snails and consequently in the definitive host progressively decreased with the altitude of snail habitats: at $2000 \mathrm{~m}$, the risk is reduced by $50 \%$ and becomes negligible at $2600 \mathrm{~m}$. The risk of fasciolosis in the definitive host also decreased with increasing altitude in some countries such as southern Brazil $[4,16]$ or Uganda [23], and this would likely be due $i$ ) to a growing paucity of intermediate hosts when the altitude of areas increases, and/or ii) to lower temperatures at higher altitudes, allowing only slower development of intramolluscan stages. The difference between our results and those of the above authors is that the altitude classes used in this study range from 200 to $600 \mathrm{~m}$, while those used by the authors are considerably larger (from $1139 \mathrm{~m}$ to $3997 \mathrm{~m}$ for Howell et al. [23], for example). Under these conditions, one may wonder what factors act on the natural infection of $G$. truncatula when the altitude of its habitats exceeds $400 \mathrm{~m}$. The lower size of snail populations in these areas [53] and the hypothesis of a lower susceptibility of these $G$. truncatula to $F$. hepatica miracidia may partially explain this decrease in the prevalence of natural infection. The existence of specific 


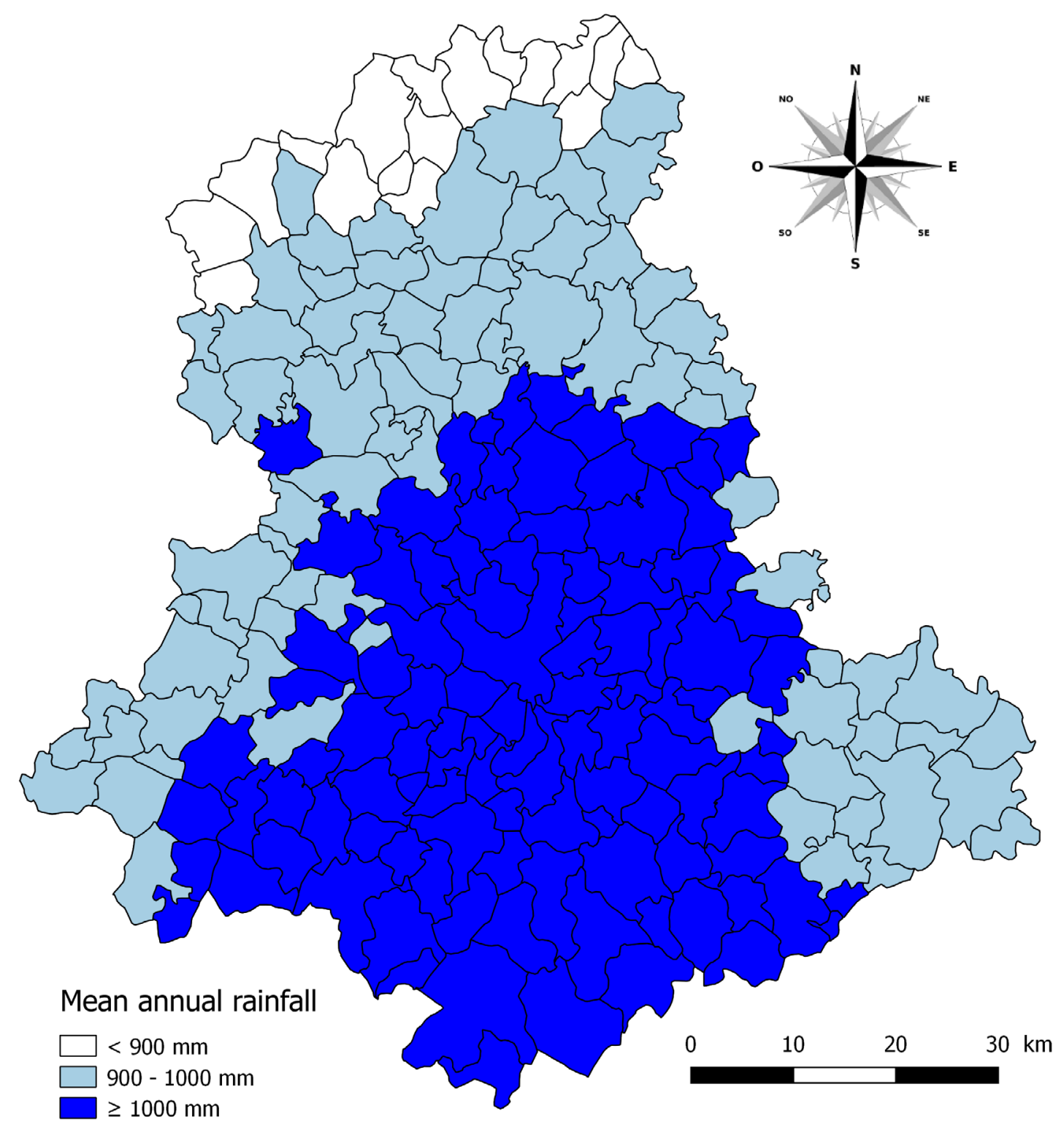

Figure 3. Mean annual rainfall from 1971 to 2000 in the 200 municipalities of the Haute-Vienne department.

ecological conditions for lymnaeids in municipalities between 400 and $600 \mathrm{~m}$, due to the predominance of conifers and perhaps to a greater acidification of running water, can also be proposed to explain our results.

To complete the life cycle of the parasite, the environment must provide a consistent set of suitable conditions of temperature and moisture for the development of the larval stages and the development of the intermediate host itself [61]. In this study, the prevalence of natural F. hepatica infection in G. truncatula decreased with lower mean annual temperatures in the municipalities, or with the increase in their average annual rainfall. The effect of temperature on the development of $G$. truncatula has been known for some time because a minimum temperature of $10^{\circ} \mathrm{C}$ is necessary for the growth of the snail [27]. Similarly, the larval forms of the parasite do not develop in snails below $10^{\circ} \mathrm{C}$ [28]. The negative effect of this climatic factor on the prevalence of $F$. hepatica infection is rather difficult to interpret. Among the hypotheses that may explain this result, the most reliable is to attribute this to the delay that an increase in altitude and, consequently, a decrease in the mean annual temperature cause on the growth of vegetation and biology of micro-invertebrates. The period during which the miracidial infection of snails takes place would be reduced in spring and autumn because of winter conditions that are longer above 400 or $500 \mathrm{~m}$ in altitude. An argument supporting this hypothesis is the existence of a single annual generation (instead of two per year usually) for $G$. truncatula in the department of Creuse, near HauteVienne, above $500 \mathrm{~m}$ [12] or in the Jura and the Alps, when altitude rises [52]. However, the possibility of a lower 


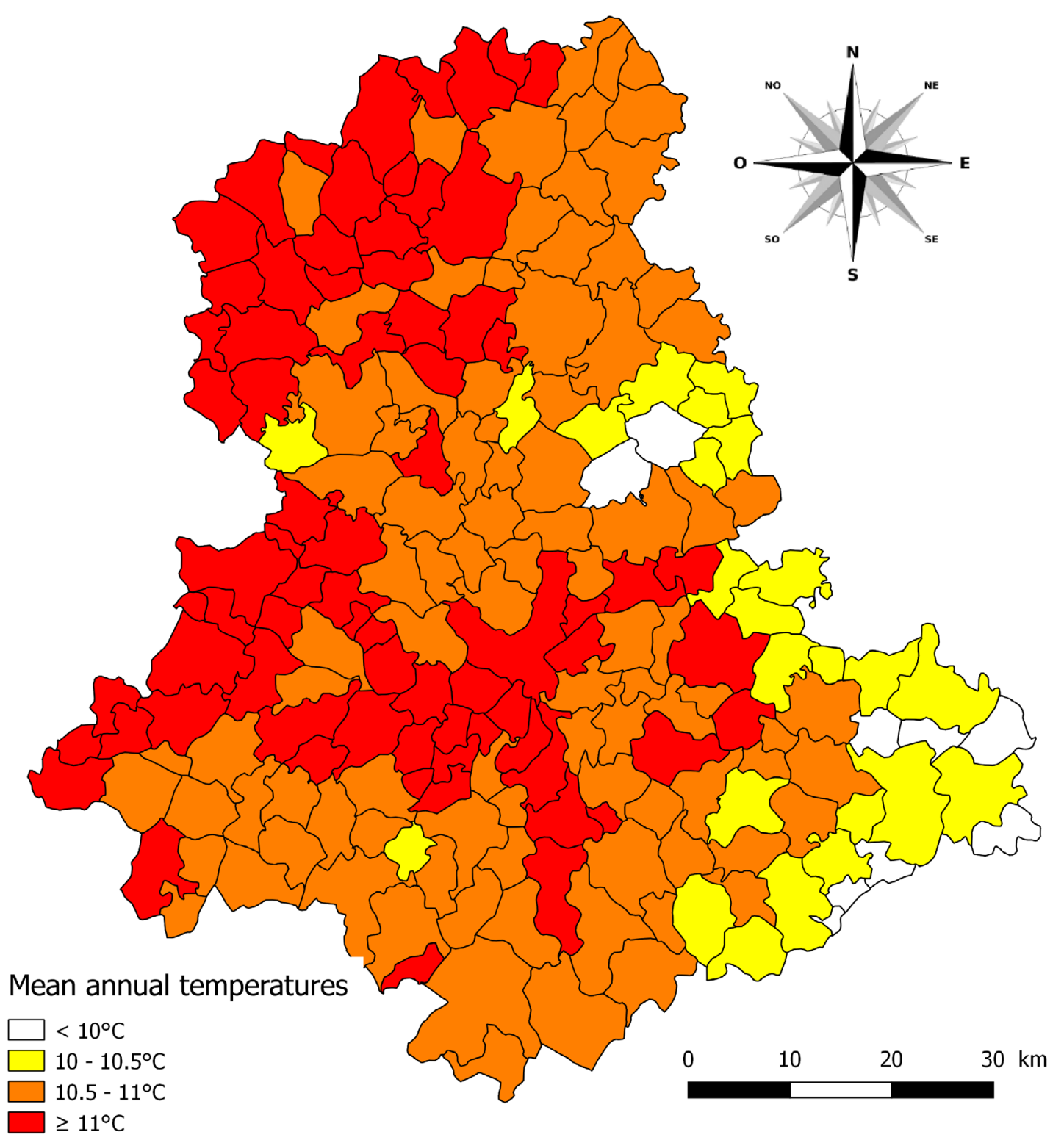

Figure 4. Mean annual temperature from 1971 to 2000 in the 200 municipalities of the Haute-Vienne department.

Fasciola infection in cattle or sheep herds when altitude rises, as demonstrated in Brazil [16] or in Uganda [23], cannot be completely excluded. In contrast to temperature, an increase in annual precipitations (from $<900$ to $>1200 \mathrm{~mm}$ per year) has a negative effect on the natural infection of snails with $F$. hepatica when they live on acid soils, even though this climatic factor is strongly correlated with the altitude of habitats and the temperature. This demonstrates that an excess in annual precipitations, as well as the drying up of the environment in which snails live [26], has a restrictive effect on the infection of snails by the parasite. Two hypotheses can be proposed to explain this last result. The first is to consider a greater dissemination of miracidia due to this excess of water and, consequently, a lower contamination of G. truncatula by $F$. hepatica. The second hypothesis is related to a greater acidification of these soils on granite or gneiss when a surplus of atmospheric precipitations occurs [20], which would not allow optimal development of $G$. truncatula populations but would affect their infection by modifying the performances of miracidia or by eliminating them.

In conclusion, the prevalence of $F$. hepatica infection in G. truncatula shows a significant decrease when the altitude of their habitats and the mean annual precipitations rise, or when the mean annual temperature decreases. Studying the prevalence of infection in these snails thus makes it possible to delineate zones at risk for fasciolosis on the acid soils of Haute-Vienne. The risk of infection for livestock would be greater in areas below $400 \mathrm{~m}$ in altitude and would gradually decrease when the 
Table 5. Values provided by a simple linear regression when used to calculate the relationship between the prevalence of natural infection with Fasciola hepatica in snails and the mean altitude, mean annual rainfall or mean annual temperature in different municipalities of Haute-Vienne. Df, degrees of freedom.

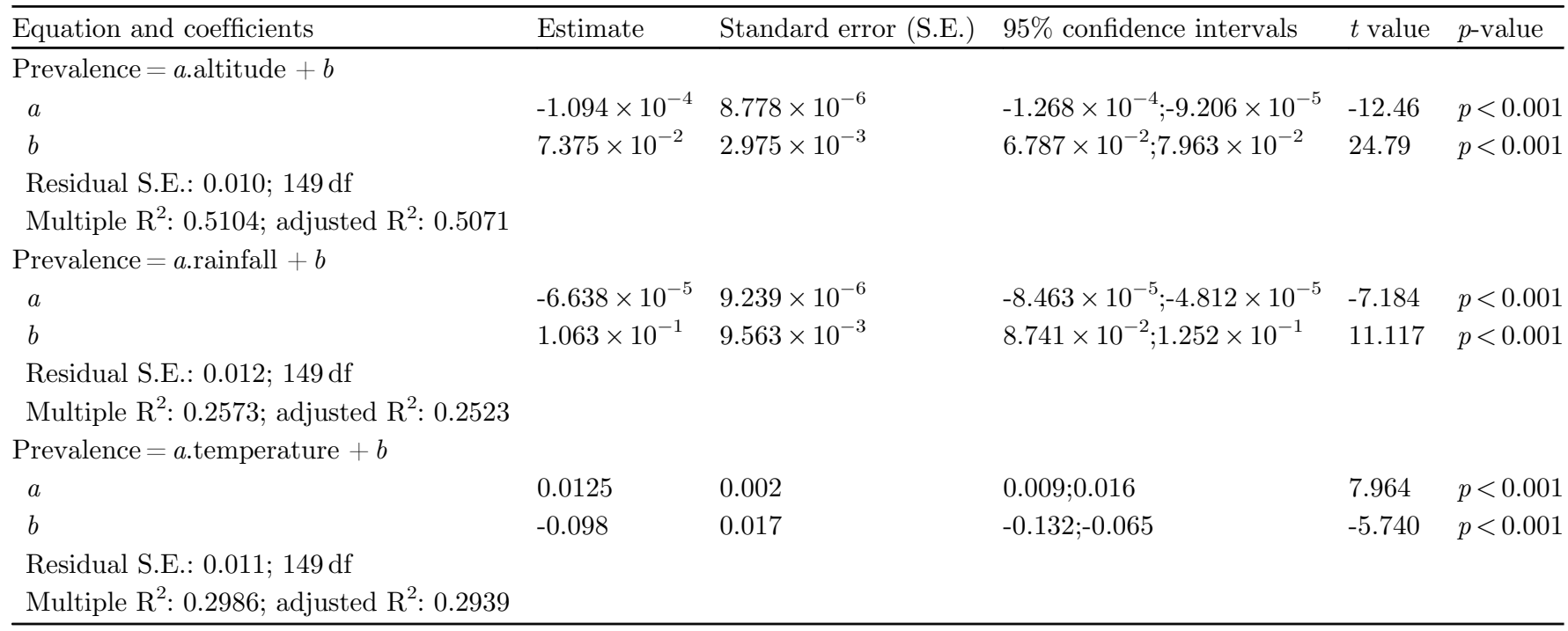

altitude of the land increases. Further observations are needed to confirm these results in other French regions or other temperate countries on acid soils.

Acknowledgements. The authors gratefully thank Dr M. Abrous and Dr C. Vareille-Morel for providing their data on the snail samples they collected in the Haute-Vienne department during their studies.

\section{Conflict of interest}

The authors declare that they have no conflicts of interest in relation to this article.

\section{References}

1. Abrous M, Rondelaud D, Dreyfuss G, Cabaret J. 1999. Infection of Lymnaea truncatula and Lymnaea glabra by Fasciola hepatica and Paramphistomum daubneyi in farms of central France. Veterinary Research, 30, 113-118.

2. Abrous M, Rondelaud D, Dreyfuss G. 2000. A field study of natural infections in three freshwater snails with Fasciola hepatica and/or Paramphistomum daubneyi in central France. Journal of Helminthology, 74, 189-194.

3. Aleixo MA, Freitas DF, Dutra LH, Malone J, Martins IVF, Molento MB. 2015. Fasciola hepatica: epidemiology, perspectives in the diagnostic and the use of geoprocessing systems for prevalence studies. Semina: Ciências Agrárias, Londrina, 36, 1451-1466.

4. Alves DP, Carneiro MB, Martins IVF, Bernardo CC, Donatele DM, Pereira Júnior OS, Almeida BR, Avelar BR, Leão AGC. 2011. Distribution and factors associated with Fasciola hepatica infection in cattle in the south of Espírito Santo State, Brazil. Journal of Venomous Animals and Toxins including Tropical Diseases, 17, 271-276.
5. Andrews SJ. 1999. The life cycle of Fasciola hepatica, in Fasciolosis, Dalton JP, Editor. CABI Publishing: Wallingford, Oxon, UK, p. 1-29.

6. Baggenstos R, Dahinden T, Torgerson PR, Bär H, Rapsch C, Knubben-Schweizer G. 2016. Validation of an interactive map assessing the potential spread of Galba truncatula as intermediate host of Fasciola hepatica in Switzerland. Geospatial Health, 11, 137-143.

7. Boray JC. 1978. The potential impact of exotic Lymnaea spp. on fascioliasis in Australasia. Veterinary Parasitology, 4, 127-141.

8. Bouet G. 1971. La production agricole du Limousin. Norois, 71, 477-489.

9. Carme B, Smyej F, Nevez G, Gingomard MA. 1996. Situation de la fasciolose en France. Études menées en Picardie. Bulletin Épidémiologique Hebdomadaire, 12/ 1996, 59.

10. Chauvin A, Zhang W, Moreau E. 2007. La fasciolose des ruminants: immunité, immunomodulation et stratégies de prévention. Bulletin de l'Académie Vétérinaire de France, $160,85-92$.

11. Chèvremont P. 2008. Carte géologique harmonisée du département de la Haute-Vienne (87). Notice technique. Orléans: BRGM/RP-57447-FR.

12. De Massias E, Rondelaud D, Mage C, Gevrey J. 1996. Lymnaea truncatula Müller dans les zones de haute altitude. Existence d'une seule génération annuelle. Bulletin de la Société Française de Parasitologie, 14, 54-61.

13. Dreyfuss G, Vignoles P, Rondelaud D. 2005. Fasciola hepatica: epidemiological surveillance of natural watercress beds in central France. Parasitology Research, 95, 278-282.

14. Dreyfuss G, Vignoles P, Rondelaud D, Cabaret J. 2015. The mud snail (Galba truncatula). Ecology, parasitism and control. Saarbrücken (Germany): Lambert Academic Publishing.

15. Fox NJ, White PCL, McClean CJ, Marion G, Evans A, Hutchings MR. 2011. Predicting impacts of climate change on Fasciola hepatica risk. PLoS One, 6, e16126. 
16. Freitas DF, Martins IVF, dos Santos GMADA, dos Santos AR, da Silva Gomes D. 2014. Bioclimatic distribution and prevalence maps for Fasciola hepatica in Espírito Santo State, Brazil. Journal of Venomous Animals and Toxins including Tropical Diseases, 20, 32.

17. Fuentes MV, Malone JB, Mas-Coma S. 2001. Validation of a mapping and predictive model for human fasciolosis transmission in Andean very high altitude endemic areas using remote sensing data. Acta Tropica, 79, 87-95.

18. Fuentes MV, Sainz-Elipe S, Nieto P, Malone JB, Mas-Coma S. 2005. Geographical Information systems risk assessment models for zoonotic fasciolosis in the South American Andes region. Parassitologia, 47, 151-156.

19. Gaillet P, Liance M, Rivollet D, Houin R. 1983. Situation de la fasciolose humaine en France. Enquête rétrospective portant sur les 30 dernières années. Bulletin de la Société Française de Parasitologie, 1, 79-82.

20. Gillman GP, Sumpter EA. 1986. Surface charge characteristics and lime requirements of soils derived from basaltic, granite and metamorphic rocks in high rainfall tropical Queensland. Australian Journal of Soil Research, 24, 173-192.

21. Guy F, Rondelaud D, Botineau M, Dreyfuss G, Ghestem A. 1996. Étude de relations entre les plantes les plus fréquentes et l'abondance de Lymnaea truncatula Müller, vecteur de Fasciola hepatica Linné dans les prairies marécageuses sur sol acide. Revue de Médecine Vétérinaire, $147,465-470$.

22. Halimi M, Farajzadeh M, Delavari M, Arbabi M. 2015. Developing a climate-based risk map of fascioliasis outbreaks in Iran. Journal of Infection and Public Health, 8, 481-486.

23. Howell A, Mugisha L, Davies J, LaCourse EJ, Claridge J, Williams DJL, Kelly-Hope L, Betson M, Kabatereine NB, Stothard JR. 2012. Bovine fasciolosis at increasing altitudes: parasitological and malacological sampling on the slopes of Mount Elgon,Uganda. Parasites and Vectors, $5,196$.

24. Iglesias-Piñeiro J, González-Warleta M, Castro-Hermida JM, Córdoba M, González-Lanza C, Manga-González Y, Mezo M. 2016. Transmission of Calicophoron daubneyi and Fasciola hepatica in Galicia (Spain): Temporal follow-up in the intermediate and definitive hosts. Parasites and Vectors, 9, 610

25. Kaplan RM. 2001. Fasciola hepatica: a review of the economic impact in cattle and considerations for control. Veterinary Therapeutics, 2, 40-50.

26. Kendall SB. 1949. Bionomics of Limnaea truncatula and the parthenitae of Fasciola hepatica under drought conditions. Journal of Helminthogy, 23, 57-68.

27. Kendall SB. 1953. The life-history of Limnaea truncatula under laboratory conditions. Journal of Helminthology, 27, $17-28$.

28. Kendall SB. 1965. Relationships between the species of Fasciola and their molluscan hosts. Advances in Parasitology, 3, 59-98.

29. Leimbacher F. 1973. Étude de l'effet de quelques facteurs climatiques sur l'évolution épizootique de Fasciola hepatica. Leur utilisation pour la mise au point d'une méthode de la prévision de l'incidence de la fasciolose en France. Haliotis, $3,43-55$.

30. Linnaeus C. 1758. Systema naturae per regna tria naturae, secundum classes, ordines, genera, species, cum characteribus, differentiis, synonymis, locis. 10th edit. Vermes, Testacea, p. [1-4], 1-824. Holmiae (Salvius).

31. Mage C. 1989. Epidémiologie de l'infestation par Fasciola hepatica chez les bovins en Limousin (France). Revue de Médecine Vétérinaire, 140, 407-411.
32. Mage C, Bourgne H, Toullieu JM, Rondelaud D, Dreyfuss G. 2002. Fasciola hepatica and Paramphistomum daubneyi: changes in prevalences of natural infections in cattle and in Lymnaea truncatula from central France over the past 12 years. Veterinary Research, 33, 439-447.

33. Malone JB, Gommes R, Hansen J, Yilma JM, Slingenberg J, Snijders F, Nachtergaele F, Ataman E. 1998. A geographic information system on the potential distribution of Fasciola hepatica and F. gigantica in east Africa based of Food and Agriculture Organization database. Veterinary Parasitology, 78, 87-101.

34. Malone JB, Yilma JM. 1999. Predicting outbreaks of fasciolosis: from Ollerenshaw to satellites, in Fasciolosis, Dalton JP, Editor. CABI Publishing: Wallingford, Oxon, UK, p. 151-183.

35. Malone JB, Bergquist NR, Huh OK, Bavia ME, Bernardi M, El Bahy MM, Fuentes MV, Kristensen TK, McCarroll JC, Yilma JM, Zhou XN. 2001. A global network for the control of snail-borne disease using satellite surveillance and geographic information systems. Acta Tropica, 79, 7-12.

36. Manga-González Y, González-Lanza C, Otero-Merino CB. 1991. Natural infection of Lymnaea truncatula by the liver fluke Fasciola hepatica in the Porma Basin, León. NW Spain. Journal of Helminthology, 65, 15-27.

37. Mas-Coma S, Bargues MD, Valero MA. 2005. Fascioliasis and other plant-borne trematode zoonoses. International Journal for Parasitology, 35, 1255-1278.

38. Mas-Coma S, Valero MA, Bargues MD. 2009a. Fasciola, lymnaeids and human fascioliasis, with a global overview on disease transmission, epidemiology, evolutionary genetics, molecular epidemiology and control. Advances in Parasitology, 69, 41-146.

39. Mas-Coma S, Valero MA, Bargues MD. 2009b. Climate change effects on trematodiases, with emphasis on zoonotic fascioliasis and schistosomiasis. Veterinary Parasitology, $163,264-280$.

40. Météo France 2016. Météo France: actualités sur la météo et le climat, dossiers, infographies, vidéos. Available from: http://www.meteofrance.fr/ (accessed on 16 December 2016).

41. Müller OF. 1774. Vermium terrestrium et fluviatilium. Historia, seu animalum infusoriorum, helinthicorum, et testaceorum, non marinorum, succincta historia. Volumen alterum. Havniae \& Lipsiae (usw.) Heineck \& Faber.

42. Novobilský A, Novák J, Björkman C, Höglund J. 2015. Impact of meteorological and environmental factors on the spatial distribution of Fasciola hepatica in beef cattle herds in Sweden. BMC Veterinary Research, 11, 128.

43. Ollerenshaw CB. 1971. Some observations on the epidemiology of fascioliasis in relation to the timing of molluscicide applications in the control of the disease. Veterinary Record, $88,152-164$.

44. Ollerenshaw CB. 1974. Forecasting liver-fluke disease, in The effects of meteorological factors upon parasites, Taylor AR, Muller R, Editors. Symposium of the British Society for Parasitology, vol. 12: Blackwell Scientific Publications, Oxford, UK, p. 3-52.

45. Ollerenshaw CB, Rowlands WT. 1959. A method of forecasting incidence of fascioliasis in Anglesey. Veterinary Record, 71, 591-598.

46. Ollerenshaw CB, Smith LP. 1969. Meteorological factors and forecast of helminthic diseases. Advances in Parasitology, 7, 283-323.

47. Olsen A, Frankena K, Bødker R, Toft N, Thamsborg SM, Enemark HL, Halasa T. 2015. Prevalence, risk factors and spatial analysis of liver fluke infections in Danish cattle herds. Parasites and Vectors, 8, 160. 
48. Rapsch C, Dahinden T, Heinzmann D, Torgerson PR, Braun U, Deplazes P, Hurni L, Bär H, Knubben-Schweizer G. 2008. An interactive map to assess the potential spread of Lymnaea truncatula and the free-living stages of Fasciola hepatica in Switzerland. Veterinary Parasitology, 154, 242-249.

49. R Core Team 2016. R: a language and environment for statistical computing. Vienna: R Foundation for Statistical Computing. Available at: https://www.R-project.org (accessed on 27 May 2016).

50. Rondelaud D. 1980. Données épidémiologiques sur la distomatose humaine à Fasciola hepatica L. dans la région du Limousin, France. Les plantes consommées et les limnées vectrices. Annales de Parasitologie Humaine et Comparée, $55,393-405$.

51. Rondelaud D. 1991. Les cressonnières naturelles du Limousin et leur contamination par Fasciola hepatica L. Bilan d'une enquête de 20 années. Annales Scientifiques du Limousin. 7, 3-14.

52. Rondelaud D. 2004. Cressonnières naturelles du Limousin et risques de distomatose humaine à Fasciola hepatica. Annales Scientifiques du Limousin, 15, 1-14. Available online in the Annales Scientifiques du Naturaliste (2012).

53. Rondelaud D, Mage C. 1992. Lymnaea truncatula Müller: les conséquences d'une seule génération annuelle sur les caractéristiques de l'infestation par Fasciola hepaticaL. Revue de Médecine Vétérinaire, 143, 843-846.

54. Rondelaud D, Amat-Frut E, Pestre-Alexandre M. 1982. La distomatose humaine à Fasciola hepatica L. Étude épidémiologique de 121 cas survenus sur une période de 25 ans. Bulletin de la Société de Pathologie Exotique, 75, 291-300.

55. Rondelaud D, Dreyfuss G, Bouteille B, Dardé ML. 2000. Changes in human fasciolosis in a temperate area. About some observations over a 28-year period in central France. Parasitology Research, 86, 753-757.

56. Rondelaud D, Vignoles P, Abrous M, Dreyfuss G. 2001. The definitive and intermediate hosts of Fasciola hepatica in the natural watercress beds in central France. Parasitology Research, 87, 475-478.
57. Rondelaud D, Vignoles P, Dreyfuss G. 2009. La Limnée tronquée, un mollusque d'intérêt médical et vétérinaire. Limoges: PULIM.

58. Rondelaud D, Hourdin P, Vignoles P, Dreyfuss G, Cabaret J. 2011. The detection of snail host habitats in liver fluke infected farms by use of plant indicators. Veterinary Parasitology, 181, 166-173.

59. Schweizer G, Meli ML, Torgerson PR, Lutz H, Deplazes P, Braun U. 2007. Prevalence of Fasciola hepatica in the intermediate host Lymnaea truncatula detected by real time TaqMan PCR in populations from 70 Swiss farms with cattle husbandry. Veterinary Parasitology, 150, 164-169.

60. Selemetas N, Ducheyme E, Phelan P, O'Kiely P, Hendrickx G, de Waal T. 2015. Spatial analysis and risk mapping of Fasciola hepatica infection in dairy herds in Ireland. Geospatial Health, 9, 281-291.

61. Torgerson P, Claxton J. 1999. Epidemiology and control, in Fasciolosis, Dalton JP, Editor. CABI Publishing: Wallingford, Oxon, UK, p. 113-149.

62. Tum S, Puotinen ML, Copeman DB. 2004. A geographic information system model for mapping risk of fasciolosis in cattle and buffaloes in Cambodia. Veterinary Parasitology, 122, 141-149.

63. Tum S, Puotinen ML, Skerratt LF, Chan B, Sothoeun S. 2007. Validation of a geographic information system model for mapping the risk of fasciolosis in cattle and buffaloes in Cambodia. Veterinary Parasitology, 143, 364-367.

64. Vareille-Morel C, Rondelaud D, Dreyfuss G. 2002. Experimental colonization of new habitats by Galba truncatula O.F. Müller (Gastropoda: Lymnaeidae) in central France and their susceptibility to experimental infection with Fasciola hepatica. Annales de Limnologie-International Journal of Limnology, 38, 35-40.

65. Vignoles P, Dreyfuss G, Rondelaud D. 2017. Écologie et parasitisme de la Limnée étroite (Omphiscola glabra). Limoges: PULIM.

66. Yilma JM, Malone JB. 1998. A geographic information system forecast model for strategic control of fasciolosis in Ethiopia. Veterinary Parasitology. 78, 103-127.

Cite this article as: Vignoles P, Rondelaud D, Dreyfuss G. 2017. Determination of zones at risk for fasciolosis in the department of Haute-Vienne, central France: a retrospective study on natural infections detected in 108,481 Galba truncatula for 37 years. Parasite 24, 55

\section{PARASTE}

An international open-access, peer-reviewed, online journal publishing high quality papers on all aspects of human and animal parasitology

Reviews, articles and short notes may be submitted. Fields include, but are not limited to: general, medical and veterinary parasitology; morphology, including ultrastructure; parasite systematics, including entomology, acarology, helminthology and protistology, and molecular analyses; molecular biology and biochemistry; immunology of parasitic diseases; host-parasite relationships; ecology and life history of parasites; epidemiology; therapeutics; new diagnostic tools.

All papers in Parasite are published in English. Manuscripts should have a broad interest and must not have been published or submitted elsewhere. No limit is imposed on the length of manuscripts.

Parasite (open-access) continues Parasite (print and online editions, 1994-2012) and Annales de Parasitologie Humaine et Comparée (1923-1993) and is the official journal of the Société Française de Parasitologie. 